\title{
OPTIMIZING THE CUT OFF GRADE IN SARCHESHMEH COPPER MINE USING LANE QUARTET MODEL
}

\author{
B. Maleki ${ }^{1, \#}$, E. Mozaffari ${ }^{1}$, M.J. Mahdavipour ${ }^{2}$ \\ ${ }^{1}$ Imam Khomeini International University, Department of Mining and Petroleum, Iran \\ ${ }^{2}$ Sarcheshmeh Copper Complex, Mining Engineering Division, Iran
}

(Received: April 20, 2016; Accepted: November17, 2016)

\begin{abstract}
Lane Algorithm is used to determine optimum cut off grade for a mining operation. There may be three parts in each operation: mining, concentration and refining. In Sarcheshmeh Copper Mine the concentrate coming from the stock has the average grade in addition to the production rate and cost. Therefore, the grade distribution is affected by production rate and cost parameters. The calculation of the cut off grade is done using a modified Lane Algorithm. Therefore, a mix of blending stock received from outside and the concentrate from the mine was considered in the Lane Algorithm. Initially, the profit objective function was taken into account with the addition of the stock limitations; then, the Lane Quartet Model was used and the cut off grade determined. The model uses the technical and economical data of different parts to determine the cut off grade. The result of the model was a cut off grade of (0.1408\%), which brings about an increase of 848051645 US dollars as profit, in comparison to the cut off grade $(0.1617 \%)$ that was obtained by the Lane tripartite model.
\end{abstract}

Key words: production management; cut off grade; Lane quartet mode; Sarcheshmeh Copper Mine.

\section{Introduction}

Production management in mining is a complicated process. Ore body characteristics are one of the most important factors. The grade distribution of minerals in deposits plays a key role in mining projects. The cut off grade is defined as a minimum grade which gives rise to economical mining. The overall grade takes into account two issues: first, in mining operation, to decide whether to continue extraction of the mineral block or give up, and the second, what would be the specifications of the material extracted and can it provide the needed requirements [1]? If the cut off grade is calculated on the basis of the break-even analysis, then the time value of money, the deposit grade distribution, the mine capacities, the concentrator plant, the refinery and the sales market are not considered directly. The breakeven cut off grade method could hardly lead to the optimized operations [2]. To solve this problem Lane Model can be used. In this Model, the mining operations are divided into three parts: extraction from the mine, concentrate production and refining. According to this model, six cut off grade values are calculated. The model incorporates an objective function, which should be satisfied by these values. Only one of these six cut off grade values is technically and economically can maximize the objective function [3].

Whittle and Wharton by applying the opportunity cost improved the Lane technique

${ }^{\#}$ Corresponding author: Maleki@eng.ikiu.ac.ir 
[4]. This concept was referred to as the cost of delay and the cost of the change. Bascetin and Nieto provided the determination strategy of cut off grade based on Lane Algorithm and added an optimization factor [1]. Robinson and Prenn have developed a model called the GROPE that is a tool for the design and economic planning of surface mineral deposits [5]. Shinkuma and Nishiyama in their research offered a decision on the cut off grade which is slightly different from the framework of Lane Model [6]. It is called the optimal control theory. Their proposed model examined the role of deposit geometry in determination of optimal cut off grade. The use of block modeling in cut-off grade determination is significant, too [7]. The Lane model was also used considering the stockpile option [8]. The Lane Algorithm has been used to calculate the optimal cut off grade using various methods including the deletion method such as the golden ratio, the equal grade factor, and the genetic algorithms [9]. Lane Model was modified taking the role of the cost of waste into account [10]. In the Sarcheshmeh Copper Mine a mix of the concentrate and the blending stock is used. The grade of the input material to the smelting plant should be adjusted so that the result mix concentrate will be of the desired grade as a feedstock for the smelting plant. However, the blending stock is collected from different mineral plants. The blending stock has a significant role in the operating conditions and alters the grade distribution that is considered by Lane tripartite algorithm. When the blending stock is added to the production circuit, the related production rate and cost parameters are adequately incorporated on to the model. Therefore, it is essential to design a modified form of Lane Algorithm for the calculation of the cut off grade. The tonnage and grade of the purchased blending stock is adjusted according to the tonnage and grade of the run of mine. This is the 4th part which is added to the previously considered three parts available in the Lane Algorithm [11].

\section{The Definition of the model}

This model is defined based on Sarcheshmeh Porphyry Copper Mine. In this mining project four parts are considered: extraction, processing, blending stock, and refining unit. In order to simplify the model, it is assumed to be a single metal deposit, the grade distribution is linear and the price is fixed. The average grade of the imported blending stock is adjusted as it is added to the concentrate from the plant to provide a desired average grade for the refinery input. The breakeven cut off grade is accepted as first grade to determine the tonnage - grade distribution for the run of mine [11]. As shown in Figure 1, the quartet model and its components in which the blending stock, as a fourth part, is highlighted.

The parameters used in the quartet model include:

\section{a) Capacities}

M: the annual run of mine both ore and waste in tones

$\mathrm{C}$ : the annual concentrate produced in processing plant in tones,

$\mathrm{R}$ : the annual production rate of the smelter and refinery in tones,

B: the annual concentrate consumption of blending stock in tones.

\section{b) Costs}

$\mathrm{m}$ : the mining costs for the run of mine in tones

c: the cost of processing for a ton of feed for the processing plant

$r$ : all the costs for the final stage of production and sale, such as smelting and refining, packaging, shipping, insurance, etc. in terms of currency units per production unit.

$\mathrm{b}$ : the costs of purchasing and stocking the blending stock concentrate in terms of the currency units per tones. 


\footnotetext{
f: annual fixed costs and all expenses such as rent, administrative, repair and maintenance of roads, buildings, etc.

c) The production and parameters:

$\mathrm{T}$ : the duration of production in years

$Q_{m}$ :the total run of mine to be extracted (tone),

$Q_{c}$ : the processing plant feed (tone),

$Q_{c o n}$ :the output of processing plant (tone),

$Q_{r}$ : the final product (tone),

$Q_{b}$ : the blending stock concentrate (tone),

$y_{1}$ : the recovery factor for the processing plant (\%),
}

$y_{2}$ :the recovery factor for the smelting and refining (\%),

$y_{t}$ : the retrieval factor for of the total production (\%),

$\mathrm{g}_{m}, \mathrm{~g}_{c}, \mathrm{~g}_{r}, \mathrm{~g}_{\mathrm{b}}$ : the cut off grade of mining, concentrate, refining and bending stock, respectively.

$\overline{\mathrm{g}}_{c}$ : the average grade of material submitted to the processing plant

$\overline{\mathrm{g}}_{\text {con }}$ :the average grade of the output from the processing plant

$\overline{\mathrm{g}}_{b}$ : the average grade of the blending stock concentrate,

$\overline{\mathrm{g}}_{r}$ : the average grade of smelting and refining feed.

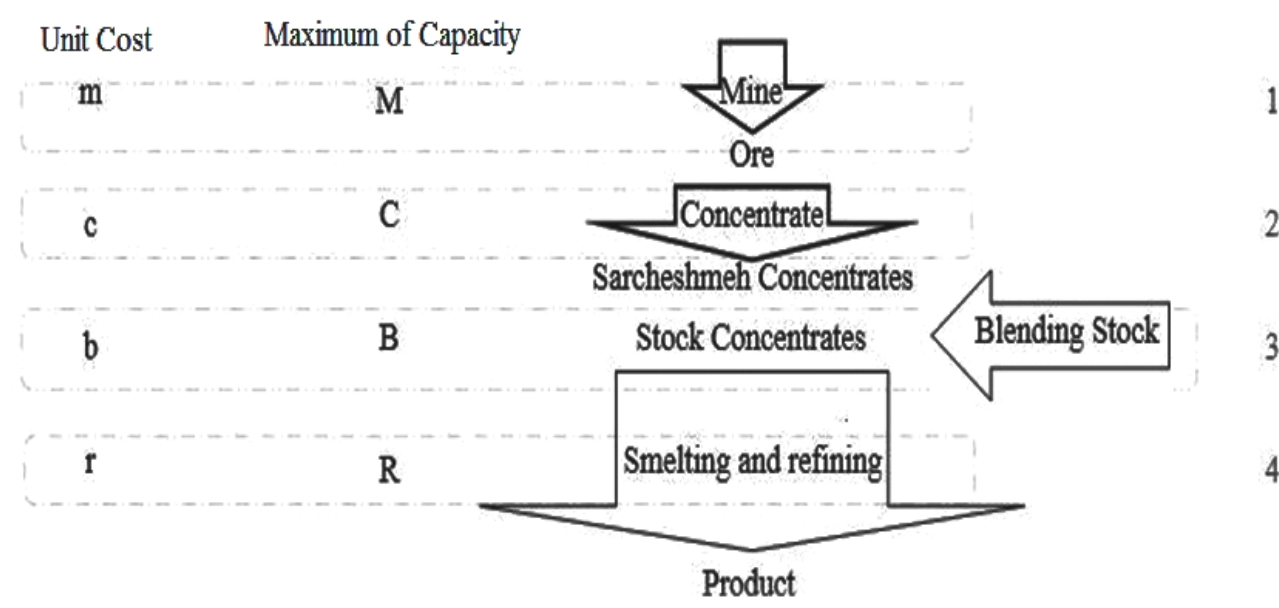

Figure 1. Quartet Model used to determine the optimal cut off grade in monometallic deposits [11]

Using the parameters presented above the profit main equation for the Lane Quartet Model can be represented as follows (Mahdavipour, 2013).

$$
\mathrm{P}=(\mathrm{s}-\mathrm{r}) Q_{r}-\left[m Q_{m}+c Q_{c}+b Q_{b}+f T\right]
$$

Tonnage and grade of the blending stock concentrate are regulated in accordance to the tonnage and grade of the Sarcheshmeh Copper Mine Concentrate required.
This shows how the new part and the existing three parts in Lane model are correlated to each other. The average grade of smelting and refining plant feed $\left(\overline{\mathrm{g}}_{r}\right)$ can be defined as eq. 2 :

$$
\overline{\mathrm{g}}_{r}=\frac{\overline{\mathrm{g}}_{c o n} Q_{c o n}+\overline{\mathrm{g}}_{b} Q_{b}}{Q_{c o n}+Q_{b}}
$$

There is always a correlation between the input and output of the mineral processing plant. 
$Q_{c} \overline{\mathrm{g}}_{c} y_{1}=Q_{c o n} \overline{\mathrm{g}}_{c o n}$

By replacing $Q_{c o n}$ from equation (3) in equation (2) and simplifying $Q_{c}$ can be obtained as eq. 4 :

$$
Q_{c}=\frac{Q_{b} \overline{\mathrm{g}}_{c o n}\left[\overline{\mathrm{g}}_{b}-\overline{\mathrm{g}}_{r}\right]}{\left[\overline{\mathrm{g}}_{c} y_{1}\left(\overline{\mathrm{g}}_{r}-\overline{\mathrm{g}}_{c o n}\right)\right]}
$$

Also, eq. 5 shows the relation between parameters $Q_{r}, Q_{c}$ and $Q_{b}$ :

$$
Q_{r}=Q_{c} \overline{\mathrm{g}}_{c} y_{t}+Q_{b} \cdot \overline{\mathrm{g}}_{b} y_{2}
$$

By substituting equations [4] and [5] in the profit main equation of Lane Quartet Model [1] we will have equation [6].

$$
\begin{aligned}
& P=\left[\left[y_{2}(s-r)-\frac{c}{\overline{\mathrm{g}}_{c} y_{1}}\right] \frac{\overline{\mathrm{g}}_{c o n}\left[\overline{\mathrm{g}}_{b}-\overline{\mathrm{g}}_{r}\right]}{\left[\overline{\mathrm{g}}_{r}-\overline{\mathrm{g}}_{c o n}\right]}\right)+\left[(s-r) \cdot \overline{\mathrm{g}}_{b} y_{2}-\right. \\
& b]] Q_{b}-m Q_{m}-f T
\end{aligned}
$$

Equation [6] is an objective function, which must be optimized by substituting the cut of grades. The required period of time for the mining project can be obtained from equation [7]:

$$
T_{m}=\frac{Q_{m}}{M}
$$

When also replaced in the main profit equation [6], equation [8] is obtained.

$$
\begin{aligned}
& P=\left[\left[y_{2}(s-r)-\frac{c}{\overline{\mathrm{g}}_{c} y_{1}}\right] \frac{\overline{\mathrm{g}}_{c o n}\left[\overline{\mathrm{g}}_{b}-\overline{\mathrm{g}}_{r}\right]}{\left[\overline{\mathrm{g}}_{r}-\overline{\mathrm{g}}_{c o n}\right]}\right)+\left[(s-r) \cdot \overline{\mathrm{g}}_{b} y_{2}-\right. \\
& b]] Q_{b}-\left[m-\frac{f}{M}\right] Q_{m}
\end{aligned}
$$

To maximize the profit, the derivative of the equation 8 with respect to grade is obtained and set equal to zero as shown in eq. 9.

$$
\frac{d P}{d \mathrm{~g}}=0
$$

It should be noted that, the amount of the ore mined is independent of the grade.
Therefore, the cut off grade $\left(\mathrm{g}_{m}\right)$ based on mining production rate constraints as eq. 10 :

$$
\mathrm{g}_{\mathrm{m}}=\frac{\mathrm{c}}{\left[\mathrm{y}_{\mathrm{t}}(\mathrm{s}-\mathrm{r})\right]+\frac{\mathrm{y}_{1}\left[\overline{\mathrm{g}}_{\mathrm{r}}-\overline{\mathrm{g}}_{\mathrm{con}}\right]\left[(\mathrm{s}-\mathrm{r}) \overline{\mathrm{b}}_{\mathrm{b}} \mathrm{y}_{2}-\mathrm{b}\right]}{\overline{\mathrm{g}}_{\mathrm{con}}\left[\mathrm{g}_{\mathrm{b}}-\overline{\mathrm{g}}_{\mathrm{r}}\right]}}
$$

Under other operational constraints, three economic cut off grade are calculated as follow:

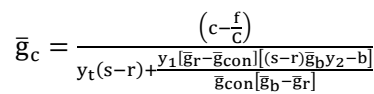

If the production rate of smelting and refining is the decisive limitation, then:

$$
\overline{\mathrm{g}}_{\mathrm{r}}=\frac{c}{\left[y_{t}\left((s-r)-\frac{f}{R}\right)\right]+\frac{\mathrm{y}_{1}\left[\overline{\mathrm{g}}_{\mathrm{r}}-\overline{\mathrm{g}}_{\mathrm{con}}\right]\left[\overline{\mathrm{g}}_{\mathrm{b}}\left(\mathrm{y}_{2}(s-r)-y_{1} \frac{f}{\mathrm{R}}\right)-b\right]}{\overline{\mathrm{g}}_{\mathrm{con}}\left[\overline{\mathrm{g}}_{\mathrm{b}}-\overline{\mathrm{g}}_{\mathrm{r}}\right]}}
$$

If the production rate of blending stock is the decisive limitation we have:

$$
\overline{\mathrm{g}}_{\mathrm{b}}=\frac{c}{y_{t}(s-r)+\frac{\mathrm{y}_{1}\left[\overline{\mathrm{g}}_{\mathrm{r}}-\overline{\mathrm{g}}_{\mathrm{con}}\right]\left[(s-r) \overline{\mathrm{g}}_{\mathrm{b}} \mathrm{y}_{2}-\mathrm{b}-\frac{f}{B}\right]}{\overline{\mathrm{g}}_{\mathrm{con}}\left[\overline{\mathrm{g}}_{\mathrm{b}}-\overline{\mathrm{g}}_{\mathrm{r}}\right]}}
$$

The Lane approach balances the three cut off grades. In Lane model three cut off grades are introduced to obtain the effective optimum cut off grade based on double limiting constraints.

However, if four parts are used instead of three parts, we have six cut off grades, which are obtained again based on double limiting constraints. There will be six of these status as can be defined: mine - mineral processing plant, mine - blending stock, mine - refinery unit, mineral processing plant - refinery unit, mineral processing plant - blending stock and blending stock - refinery unit.

In this model ten cut off grades are calculated that four of them are single limiting cut off grades $\left(\mathrm{g}_{\mathrm{m}}, \mathrm{g}_{\mathrm{c}}, \mathrm{g}_{\mathrm{b}}, \mathrm{g}_{\mathrm{r}}\right)$ and the other six are double limiting cut off grades.

Figure 2 is a typical demonstration of the profits obtained according to single limiting cut off grades. 
As can be seen, the effective economical profit $\left(P_{e}\right)$, in which all the constraints are considered, is an envelope curve of the other four curves.

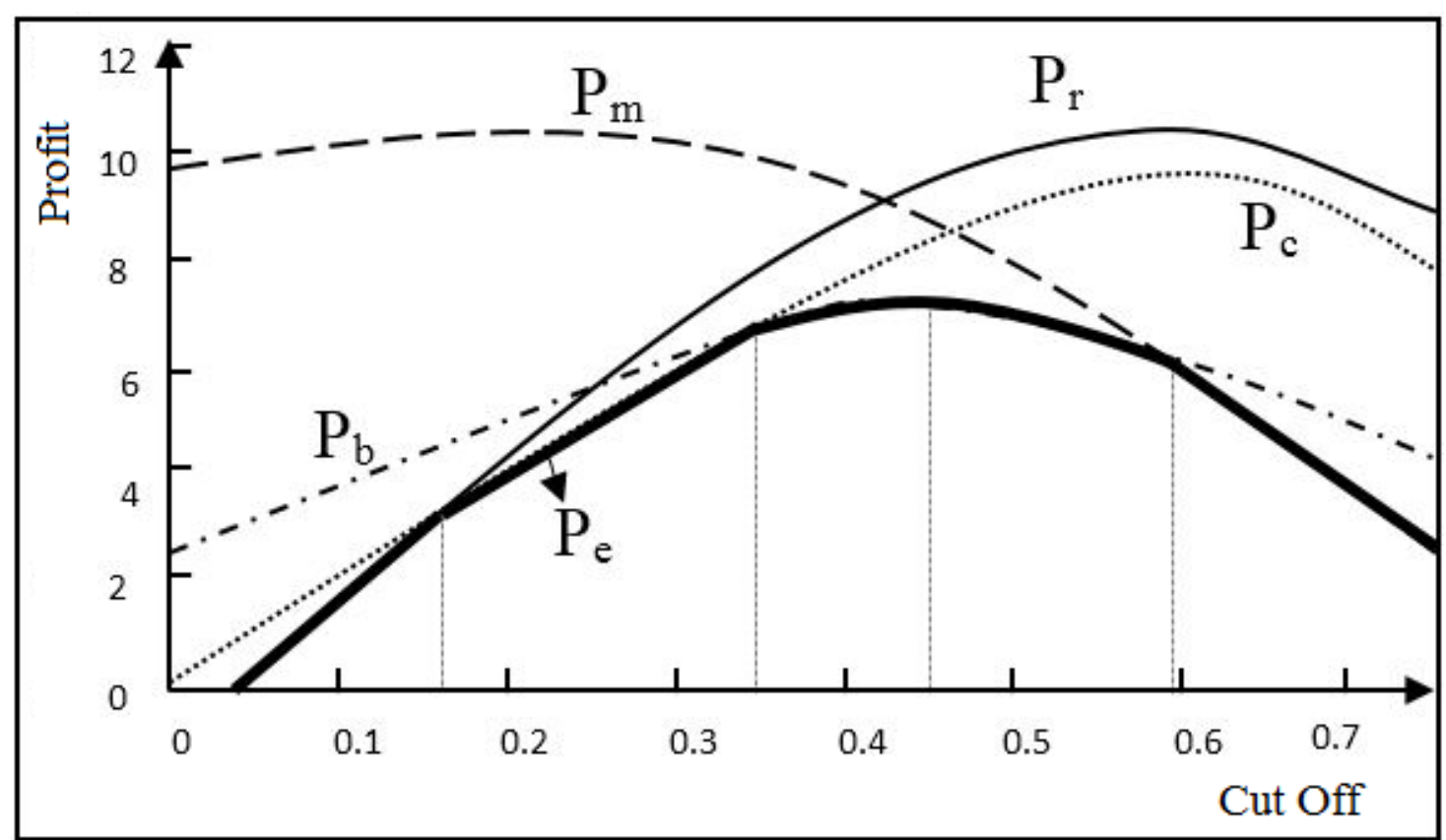

Figure 2. Typical demonstration of $\mathrm{P}_{\mathrm{e}}$ against $\mathrm{P}_{\mathrm{m}}{ }^{6} \mathrm{P}_{\mathrm{c}}{ }^{6} \mathrm{P}_{\mathrm{b}}$ and $\mathrm{P}_{\mathrm{r}}$ in quartet model [11]

Also, for every six double limiting constraint a related profit can be defined. In this case, the effective economical profit $\left(P_{e}\right)$ will be an envelope curve of the other 10 curves.

\section{Case Study}

The economical and operational data obtained from different units of Sarcheshmeh Copper Mine are given in Table 1, which are used in the model. The results of optimal cut off grade both for the Lane tripartite model (Figure 3) and for the Lane quartet model (Fig. 4) were determined to maximize the profit. Finally, results were compared for both models and the performance of the proposed model was presented. The data received from Sarcheshmeh Copper Mine in 2011 was used to compute the model. Table 1 shows the ore body distribution and Table 2 indicates the required model parameters [12].

As can be seen in Figure 3, there are three single limiting cut off grade curves, in which three cross points can be found. These cross points show the double limiting cut of grades. The maximum value for the envelop curve, as seen in Figure 3, is the optimal cut off grade: $0.1617 \%$ that gives the maximum profit.

In the Lane quartet model, there can be seen four curves with six cross points, as in Figure 4. Each cross point shows the double cut off grade. The maximum value for the envelop curve, as seen in Figure 4, is the optimal cut off grade: $0.1408 \%$ that gives the maximum profit. In the quartet model, the mining project is controlled by blending stock and therefore, it is recognized as a critical parameter. 
Table 1. The composition of the ore body according to grade and tonnage [12]

\begin{tabular}{|c|c|c|c|c|c|c|}
\hline $\begin{array}{l}\text { Average grade } \\
\text { in each of cut } \\
\text { off grade }\end{array}$ & $\begin{array}{c}\text { Tonnage of ore } \\
\text { in each of cut } \\
\text { off grade }\end{array}$ & $\begin{array}{c}\text { Cut off } \\
\text { grade }\end{array}$ & $\begin{array}{c}\text { Average grade } \\
\text { in each category } \\
(\mathrm{Cu} \%)\end{array}$ & \multirow{2}{*}{$\begin{array}{c}\text { Tonnage of } \\
\text { category }\end{array}$} & \multicolumn{2}{|c|}{$\begin{array}{c}\text { Grade of category } \\
(\mathrm{Cu} \%)\end{array}$} \\
\hline & & & & From & To \\
\hline 0.310 & 1290245776.9 & .0 & 0.0021 & 573343963.4 & .0 & .1 \\
\hline 0.556 & 716901813.5 & .1 & 0.1510 & 138415862.3 & .1 & .2 \\
\hline 0.653 & 578485951.2 & .2 & 0.2462 & 99533797.7 & .2 & .3 \\
\hline 0.737 & 478952153.5 & .3 & 0.3465 & 62322200.5 & .3 & .4 \\
\hline 0.795 & 416629953.0 & .4 & 0.4487 & 46943129.3 & .4 & .5 \\
\hline 0.840 & 369686823.6 & .5 & 0.5522 & 61191305.7 & .5 & .6 \\
\hline 0.896 & 308495517.9 & .6 & 0.6497 & 76426325.2 & .6 & .7 \\
\hline 0.978 & 232069192.7 & .7 & 0.7476 & 66685751.6 & .7 & .8 \\
\hline 1.071 & 165383441.1 & .8 & 0.8469 & 50973015.1 & .8 & .9 \\
\hline 1.170 & 114410426.1 & .9 & 0.9461 & 34095464.4 & .9 & 1.0 \\
\hline 1.265 & 80314961.7 & 1.0 & 1.0470 & 24165792.1 & 1.0 & 1.1 \\
\hline 1.359 & 56149169.6 & 1.1 & 1.1480 & 17055784.9 & 1.1 & 1.2 \\
\hline$\vdots$ & $\vdots$ & $\vdots$ & $\vdots$ & $\vdots$ & $\vdots$ & $\vdots$ \\
\hline 3.119 & 10000.0 & 3.0 & 3.0240 & 5000.0 & 3.0 & 3.1 \\
\hline 3.213 & 5000.0 & 3.1 & 3.2134 & 5000.0 & 3.1 & 3.2 \\
\hline
\end{tabular}

Table 2. The data from Sarcheshmeh mine according to the parameters used in Lane model [13]

\begin{tabular}{|c|c|c|c|}
\hline Symbol & Stage & Value & Unites \\
\hline $\mathrm{M}$ & Mine & 55000000 & tones \\
\hline $\mathrm{C}$ & Concentrate & 23000000 & tones \\
\hline $\mathrm{B}$ & Blending & 232000 & tones \\
\hline $\mathrm{R}$ & Smelting and Refining & 150000 & tones \\
\hline$y_{1}$ & Concentrate & 86 & $\%$ \\
\hline$y_{s}$ & Smelting & 91 & $\%$ \\
\hline$y_{r}$ & Refining & 84 & $\%$ \\
\hline$y_{2}$ & Smelting and Refining & 77 & $\%$ \\
\hline$y_{t}$ & Total & 66 & $\%$ \\
\hline $\mathrm{m}$ & Mine & 153.1 & $\$ /$ tone \\
\hline $\mathrm{c}$ & Concentrate & 316.8 & $\$ /$ tone \\
\hline $\mathrm{b}$ & Blending & 3996.7 & $\$ /$ tone \\
\hline $\mathrm{r}$ & Smelting and Refining & 2153.3 & $\$ /$ tone \\
\hline $\mathrm{f}$ & Annual fixed costs & 34910277.3 & $\$ /$ year \\
\hline $\mathrm{s}$ & Price & 8969.5 & $\$ /$ tone \\
\hline $\bar{g}_{\text {con }}$ & Concentrated condensed & 25.14 & $\%$ \\
\hline $\bar{g}_{b}$ & Concentrated stock & 29.15 & $\%$ \\
\hline $\bar{g}_{r}$ & Feed concentrate & 27.14 & $\%$ \\
\hline
\end{tabular}




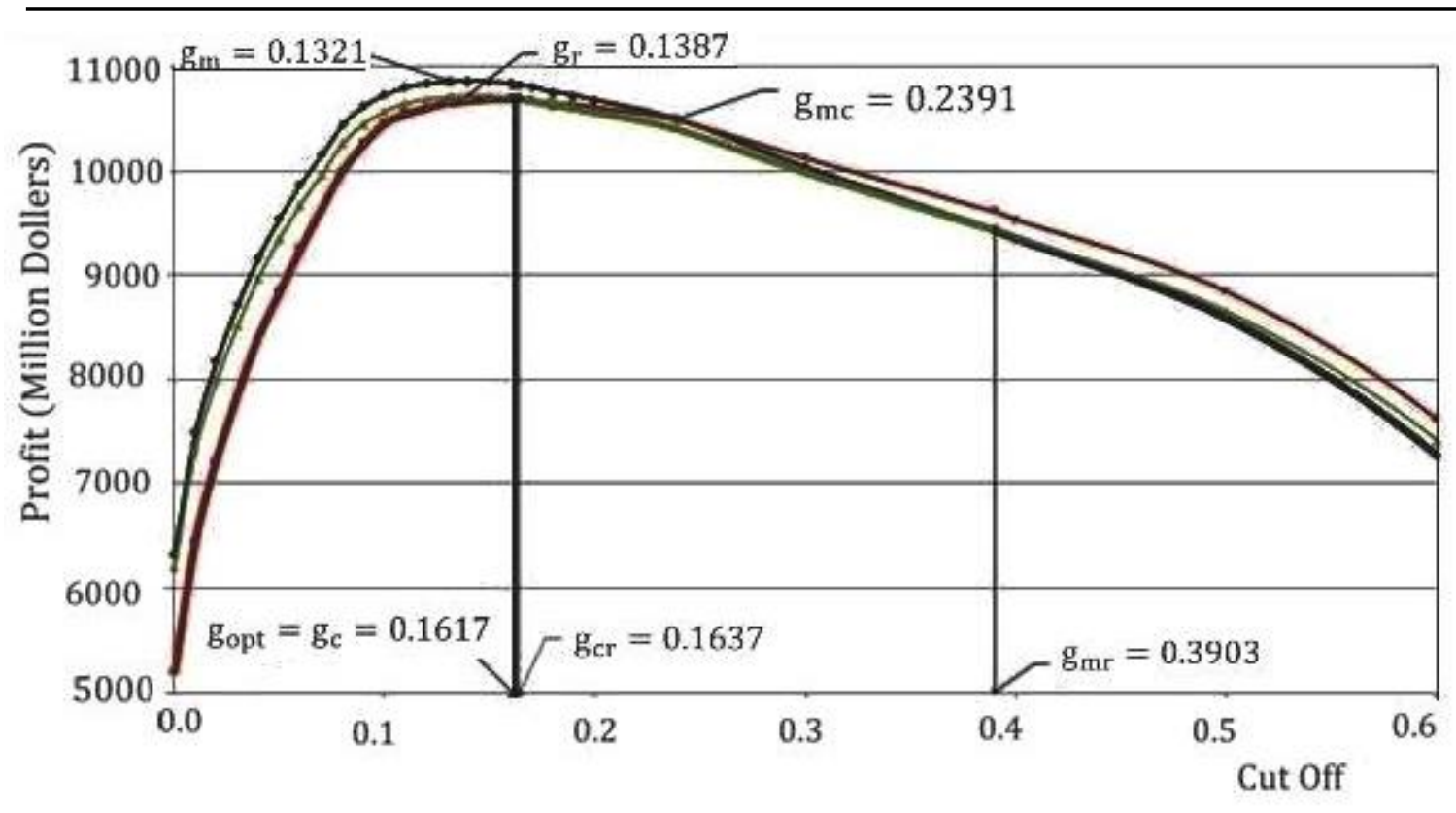

- Mine - Concentrate - Smelting and Refining

Figure 3. The profit changes based on cut off grade under various constraints for Sarcheshmeh Copper Mine in the Lane Tripartite Model [11]

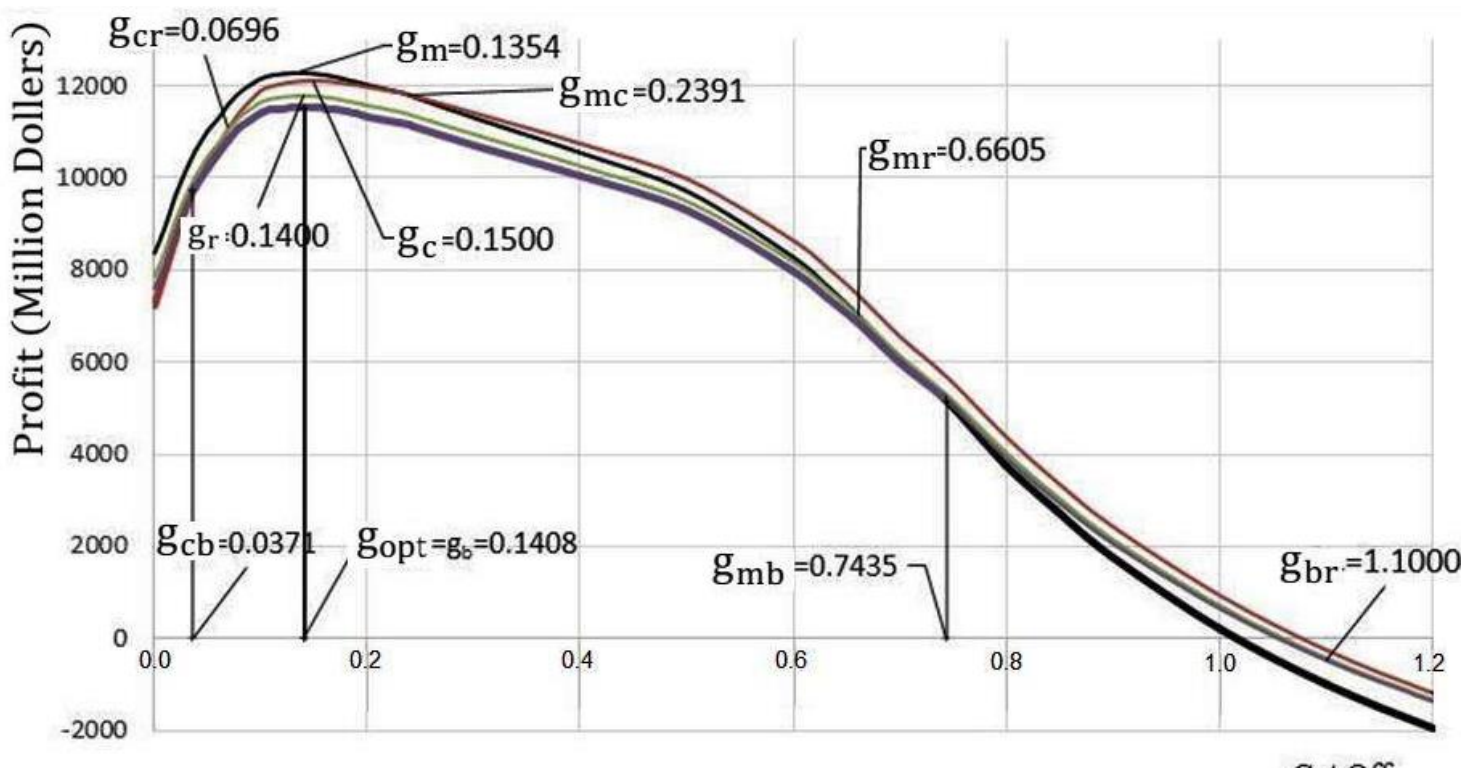

Cut Off

- Mine Concentrate $\longrightarrow$ Smelting \& Refining — Blending stock

Figure 4. The profit changes based on cut off grade under various constraints for Sarcheshmeh Copper Mine in the Lane Quartet Model [11] 


\section{Conclusions}

According to the Lane tripartite algorithm the optimal cut off grade equals to $0.1617 \%$. The profit received using this cut off grade was calculated to be equal to 10687478146 US \$. In the proposed model, the optimal cut off grade was calculated to be equal to $0.1408 \%$. The profit made by using this quartet model is also 11535529791 US \$. Therefore, it can be seen that under the proposed quartet model 848051645 US \$ more profit can be saved. The addition of the forth part, the blending stock, gives rise to the better regulation of the other triple parts resulting in a higher profit for the Sarcheshmeh Copper Mine.

The proposed model conforms well to the large mines such as Sarcheshmeh Copper Mine with diversified production constraints. The system productivity may be increased by extending the model to consider stock pile options and multi metal deposits [14]. In Sarcheshmeh Copper Mine, molybdenum as a byproduct can generate income while Iron oxide mineral can be regarded as penalty, in which both can play a role in the model. Therefore, in order to increase the adaptation of the proposed model, with the actual conditions and production constraints, some more parameters should be included in the model.

\section{Appreciation}

The authors would like to thank Imam Khomeini International University and Sarcheshmeh Copper Mine for their support in doing this research.

\section{References}

[1] Bascetin, A., Nieto, A. (2007) Determination of optimal cut-off grade policy to optimize NPV using a new approach with optimization factor, The Journal of the Southern African Institute of Mining and Metallurgy, 107, 87-94.

[2] Dagdelen, K. (1993) An NPV optimization algorithm for open pit mine design, In: 24th International Symposium on Application of Computers and Operations Research in the Mineral Industry, Montreal, Quebec, Canada, 257-263.

[3] Lane, K.F. (1988) The economic definition of ore, cut-off grade in theory and practice, Mining Journal, Books Ltd., London.

[4] Whittle, J., Wharton, C. (1995) Optimizing cutoffs over time, In: Proceedings of 25th International Symposium on Application of Computers and Mathematics in the Mineral Industries, Brisbane, 261-265.

[5] Robinson, R.H., Prenn, N.B. (1988) An open pit design model, Mining Journal, Books Ltd., London.

[6] Shinkuma, T., Nishiyama, T. (2000) The grade selection rule of the metal mines: an empirical study on copper mines, Resources Policy, 31-38.

[7] Yasrebi, A.B., Wetherelt, A., Foster, P., Afzal, P., Ahangaran, K., (2015), Determination of an optimum voxel size based on statistical methods in the kahang cu porphyry deposit, central Iran, Journal of Mining and Metallurgy, 51A (1): $21-27$.

[8] Asad, M.W.A., Topal, E. (2011) Net present value maximization model for optimum cut-off grade policy of open pit mining operations, The Journal of the Southern African Institute of Mining and Metallurgy, 111(11), 741-750.

[9] Ataei, M., Osanloo, M. (2004) Using a combination of genetic algorithm and the grid search method to determine optimum cut-off grades of multiple metal deposits, International Journal of Mining, 
Reclamation and Environment, 18(1), 60 $-78$

[10] Gholamnejad, J. (2009) Incorporation of rehabilitation cost in to the optimum cut off grade determination, The Journal of the Southern African Institute of Mining and Metallurgy, 19, 89-94.

[11] Mahdavipour, M.J. (2013) Determination of the optimum cut-off grade in Sarcheshmeh Copper Mine by Lane quartet algorithm, M.S. thesis, Mine and petroleum Dep., Imam Khomeini
International Uni., Qazvin, Iran. (In Persian).

[12] SRK Consulting (2011) Sarcheshmeh Copper Mine open pit design final report, SRK Consulting Co.

[13] National Iranian Copper Industries Co. (2012) Report on the financial status for different units of Sarcheshmeh Copper Mine, Industry accounting department, Document code QC-I-R-03-06.

[14] Rendu, J.M. (2009) An introduction to cut off grade estimation, SME Journal. 


\title{
OPTIMIZACIJA GRANIČNOG SADRŽAJA U SARCHESHMEH RUDNIKU BAKRA PRIMENOM LANE QUARTET MODELA
}

\author{
B. Maleki ${ }^{1, \#}$, E. Mozaffari ${ }^{1}$, M.J. Mahdavipour ${ }^{2}$ \\ ${ }^{1}$ Imam Khomeini International University, Department of Mining and Petroleum, Iran \\ ${ }^{2}$ Sarcheshmeh Copper Complex, Mining Engineering Division, Iran
}

(Primljen: 20. April 2016.; Prihvaćen: 17. Novembar, 2016.)

\begin{abstract}
Izvod
Lane algoritam je primenen za određivanje optimalnog graničnog sadržaja pri rudarskim aktivnostima koje uključuju eksploataciju, koncentraciju i rafinaciju. U rudniku bakra Sarcheshmeh sadržaj korisne komponente u koncentratu koji dolayi sa sklada je pod uticajem kapaciteta proizvodnje i parametara troškova. Proračun graničnog sadržaja je izvršen primenom modifikovanog Lane Algoritma uzimajući u obzir miks koncentrata sa stoka $i$ koncentrata koji dolazi sa rudnika. Inicijalno je u algoritmu uzet u obzir i efekat profita zajedno sa ograničenjima sklada. Inicijalno,funkcija ciljnog profita je uzeta u obzir uz dodatak ograničenja sklada a zatim je granični sadržaj određen Lane Quartet Modelom koji koristi ekonomske i tehničke podatke. Rezultat je bio granični sadržaj od $0.1408 \%$, što dovodi do povećanja profita od 848051645 US\$ u poređenju sa graničnim sadržajem od 0.1617\% koji je dobijen primenom Lane tripartidnog modela.
\end{abstract}

Ključne reči: upravljanje proizvodnjom; granični sadržaj; Lane Quartet Model; Sarcheshmeh rudnik bakra.

\footnotetext{
${ }^{\#}$ Kontakt adresa autora: Maleki@eng.ikiu.ac.ir
} 